\title{
First record of a nucleopolyhedrovirus infecting brown-tail moth larvae, Euproctis chrysorrhoea (L.) (Lepidoptera: Lymantriidae) in India
}

\author{
Barkat Hussain ${ }^{1,2^{*}}$, G. Sivakumar ${ }^{3}$, M. Kannan ${ }^{4}$, Abdul Rasheed War ${ }^{5}$ and Chandish R. Ballal ${ }^{3}$
}

\begin{abstract}
Ladakh (Jammu and Kashmir) is the coldest arid region of India, where apricot is a major fruit grown across the region. In recent years, severe infestation by the defoliating caterpillar, brown-tail moth, Euproctis chrysorrhoea (L.) (Lepidoptera: Lymantriidae), on apricot trees has been reported in and around the Batalik sector. During field surveys, dead larvae of the brown-tail moth infected with a nucleopolyhedrovirus (NPV) were found. Electron microscopic studies revealed the typical baculovirus occlusion bodies (OBs) with polyhedral structures. Under a scanning electron microscope (SEM), the OBs of Euproctis NPV appeared to have crystalline structures of variable shapes and sizes which varied from 1.016 to $1.596 \mu \mathrm{m}$. Most of the OBs were tetrahedral and few were of hexagonal in shape. The transmission electron microscope (TEM) images of the OBs revealed the tetrahedral shape. The leaf disc bioassay showed the $\mathrm{LC}_{50}$ of $1 \times 10^{4} \mathrm{OBs} / \mathrm{ml}$ against second instar larvae of Euproctis chrysorrhoea. The 95\% fiducial limits ranged from 1.416 to 2.887. This is the first report of NPV from the brown-tail moth in India from the Ladakh region. NPV being safe and environmentally friendly could be an ideal component for the integrated pest management (IPM) approach to controlling the pest.
\end{abstract}

Keywords: Euproctis chrysorrhoea, Apricot, Nucleopolyhedrovirus, Biological control

\section{Background}

Ladakh is the high-altitude cold desert region in Jammu and Kashmir and is one of the major producers of apricot in India. Recently, the outbreak of an invasive pest, the brown-tail moth, Euproctis chrysorrhoea (L.), in the Ladakh region is a bottleneck for fruit trade from this region (Tundup et al., 2016; Lamo, 2017; Bhagat, 2018). Raghuvanshi et al. (2016) reported severe infestation by this defoliating insect on apricot in the Dah-Hanu belt of Ladakh. Defoliation by this pest leads to poor quality and unmarketable fruit and renders them unfit for human consumption and commercial uses. Brown-tail moth is native to Europe but it has spread to many parts

\footnotetext{
* Correspondence: bhatbari@rediffmail.com; abdulwar2@gmail.com ${ }^{1}$ Division of Entomology, Sher-e-Kashmir University of Agricultural Sciences and Technology of Kashmir, Shalimar Campus, Srinagar 190019, India ${ }^{2}$ High Mountain Entomology Laboratory, Satkana Leh, SKUAST-Kashmir, Ladakh, India

Full list of author information is available at the end of the article
}

of the world. Dha-Biama, Darcheik, HanuThang, and Achinathang are the most affected villages of Ladakh with losses in the yield of about $50-90 \%$ caused by this pest (Tundup et al., 2016 and Raghuvanshi et al., 2016).

The brown-tail moth and its virus, Euproctis nucleopolyhedrovirus (Euptoctis NPV), are invasive to India. It has been reported in restricted places in China (You et al., 1983). The invasion of this pest is attributed to the improper quarantine regulations, and it is believed that it has arrived through tourists (Hussain et al., 2018). The pest causes heavy losses to the horticulture industry, and in addition, the larval hairs cause skin rashes in humans (Sterling, 1983; Tundup et al., 2016; Raghuvanshi et al., 2016). The larvae are polyphagous and feed on leaves of many hardwood trees and shrubs including apricot, apple, peach, pear, cherry, poplar, willow, Robinia, Rumex, sea-buckthorn, geranium, walnut, and rose, but the major economic losses occur in apricot and apple (Lamo, 2017). Due to the lack of proper management 


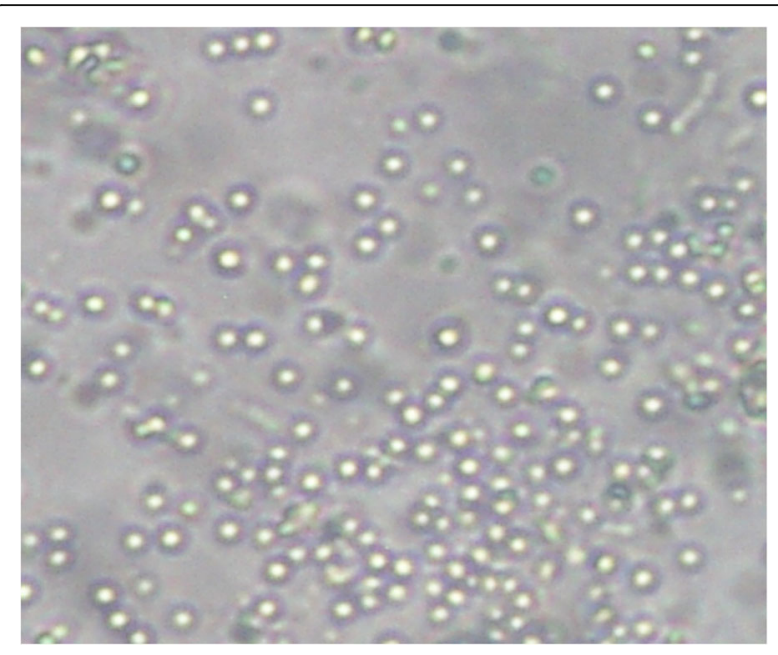

Fig. 1 Light micrograph (magnification at $10 \times 40$ ) of discharge body fluid obtained from diseased larvae of Euproctis sp. showing baculovirus occlusion bodies

and the absence of natural enemies, the pest spreads widely and rapidly causing huge losses in apricots alone (Anonymous, 2014 and Lamo, 2017). Biopesticides form an important component of the pest management program in many insect pests. These include natural enemies of insect pests (parasitoids and predators) and plant-based insecticides or microbial pesticides (fungi, bacteria, viruses, protozoa, and nematodes). Nucleopolyhedrovirus (NPV) belongs to baculoviruses that infect and kill the larvae of noctuid moths. NPV is the most studied group of viruses and is commercially used in insect pest control. Over 400 species of insects are infected by NPV (Grzywacz et al,, 2011). The NPV-infected insect larvae contain NPV particles known as polyhedral inclusion bodies (PIBs). One PIB can infect and kill a single larva. The ingested PIB allows the virus to infect the gut cells of the larva, and it spreads to almost all tissues of the body within $24 \mathrm{~h}$. A larva can be killed within 4 days once infected by NPV (Kumar et al., 2008 and Grzywacz et al., 2011).

This study was based on the hypothesis that NPV could be managing the brown tail moth under natural conditions. As such, survey and surveillance programs were launched to identify natural enemies of this pest, and it was found that the larvae collected from the Ladakh region were infected by NPV. The association of NPV with the E. chrysorrhoea was confirmed by the morphological features of the virus using electron microscopy.

\section{Materials and methods}

\section{Collection and extraction of baculovirus}

The NPV was isolated from the dead larvae of $E$. chrysorrhoea, collected from apricot trees, in the
Ladakh region of India. To release occlusion bodies (OBs), the diseased larvae were homogenised, using a sterile pestle and mortar for $4 \mathrm{~min}$ with $5 \mathrm{ml}$ of distilled water. The suspension was filtered twice through a double-layered muslin cloth and then the filtrate was centrifuged (Remi, cC24 BL, India) at 500 $\mathrm{rpm}$ for $1 \mathrm{~min}$ to remove the larger particles. The supernatant was suspended in $(5 \mathrm{ml})$ distilled water and centrifuged at $5000 \mathrm{rpm}$ for $20 \mathrm{~min}$ to collect the pellet containing polyhedra. The pellet containing OBs was re-suspended in $(5 \mathrm{ml})$ distilled water and stored at $5{ }^{\circ} \mathrm{C}$. The polyhedral occlusion bodies were counted using a haemocytometer.

\section{Electron microscopy-morphology}

The morphological studies of the extracted OBs were carried out under a scanning electron microscope (SEM) and a transmission electron microscope (TEM). The purified $\mathrm{OB}$ suspensions were taken in vials, fixed in $2.5 \%(v / v)$ glutaraldehyde and $2 \%$ paraformaldehyde in $0.1 \mathrm{M}$ phosphate buffer $(\mathrm{pH} 7.4)$ for $2 \mathrm{~h}$ at $4{ }^{\circ} \mathrm{C}$. The samples were then post-fixed in $2 \%(v / v)$ aqueous osmium tetroxide $\left(\mathrm{OsO}_{4}\right)$ prepared in $0.1 \mathrm{M}$ phosphate buffer ( $\mathrm{pH}$ 7.4) for $1 \mathrm{~h}$ and dehydrated in graded ethanol series (Martins et al., 2005). The samples were finally dried to a critical drying point. Stubs with double-sided conductivity carbon adhesive tape and sputter coated with gold for $20 \mathrm{~s}$, using an automated sputter coater (Model: EMITEC - SC 7620), were used for sample mounting. The coated samples were examined directly under a SEM (Quanta 250, FEI, Netherlands) at $10 \mathrm{kV}$ with a spot size of 3.5 and a pressure of $60 \mathrm{~Pa}$. The sample images were visualised and photographed at $\times 40,000$ magnification. The amplified photographs developed by a scale were used to measure the sizes of the OBs.

For TEM studies, the pellets of OBs were initially fixed in $2.5 \%(v / v)$ glutaraldehyde in $0.05 \mathrm{M}$ phosphate buffer $(\mathrm{pH} 7.2)$ for $24 \mathrm{~h}$ at $4{ }^{\circ} \mathrm{C}$ and again fixed in $0.5 \%(v / v)$ aqueous osmium tetroxide in the same buffer for $2 \mathrm{~h}$. After the post-fixation, samples were dehydrated in a series of graded alcohol; the dehydrated sample was mounted on 300 mesh carbon-coated copper grid. The sample was stained by saturated aqueous uranyl acetate and counterstained with lead citrate and viewed under TECNAI $120 \mathrm{Kv}$ TEM (FEI, Netherlands). The sizes of the OBs and nucleocapsids were measured directly from the amplified photographs using a precision ruler and compared to the magnification of the photograph.

\section{Bioassay}

Median lethal concentration $\left(\mathrm{LC}_{50}\right)$ of Euproctis NPV to second instar larvae was estimated by a leaf disc bioassay method (Magholi et al., 2014) with few modifications. 


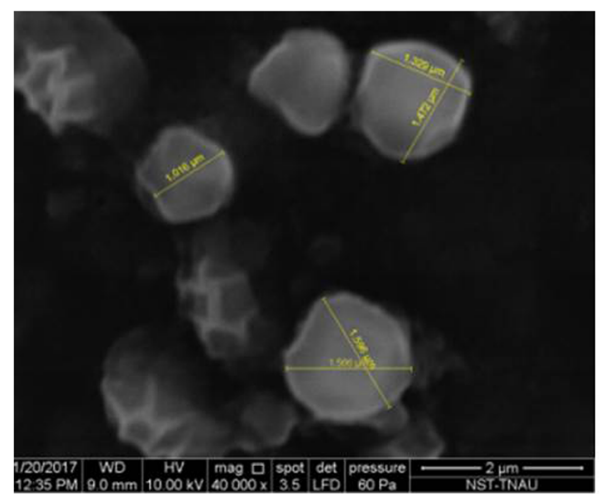

$\mathbf{a}$

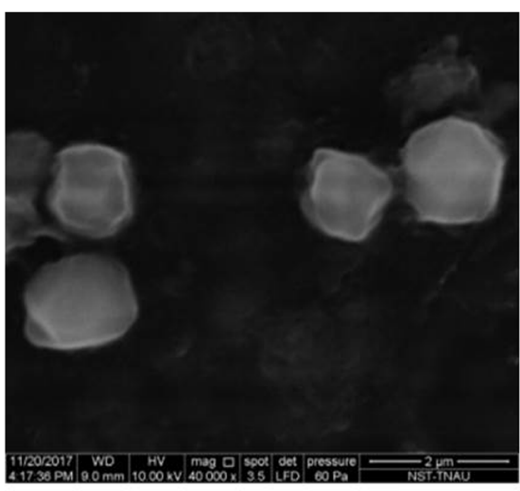

b

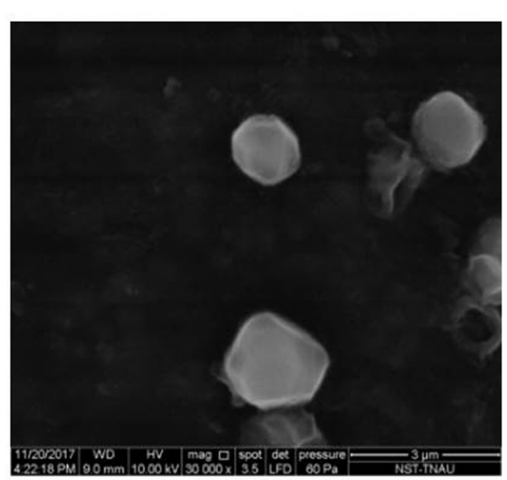

c

Fig. 2 a-c Scanning electron micrographs of polyhedral occlusion bodies extracted from baculovirus-infected larvae of a Euproctis sp.

Viral suspensions of $10^{2}, 10^{4}, 10^{6}$, and $10^{8} \mathrm{OBs} / \mathrm{ml}$ were prepared in aqueous $(0.05 \%)$ Tween $20(v / v)$. Ten microlitres of viral suspension was spread on apricot leaf discs $(2.0 \mathrm{~cm}$ diameter), air dried, and individually placed inside 12 -well tissue culture plates $(2.5 \mathrm{~cm}$ dia.). Each plate constituted an independent replication, and three plates were used per viral suspension, constituting 50 insects per treatment. Second instar E. chrysorrhoea larvae starved for about $6 \mathrm{~h}$ were released individually into the wells which were then covered with a lid. The larvae consumed the entire diet within $12 \mathrm{~h}$, then were transferred to plastic containers containing fresh apricot leaves and maintained at $26 \pm 2{ }^{\circ} \mathrm{C}$ and $60-70 \%$ relative humidity. In control, larvae were allowed to feed on leaves treated with aqueous (0.05\%) Tween 20 . Larval mortality rates were recorded at daily intervals. Mortality due to viral infection was recorded up to 9 days post inoculation.

\section{Statistical analysis}

Bioassay data were analysed, using the Probit analysis (Finney, 1971) to record the lethal concentration of virus required to cause $50 \%$ mortality $\left(\mathrm{LC}_{50}\right)$. The data was analysed by analysis of variance (ANOVA), using SPSS (v.15.1; SPSS Inc., Chicago, IL). Mortality (\%) was corrected by the following equation (Abbott 1925):

$$
M(\%) \frac{(t-c)}{(100-c)} \times 100
$$

where $M=$ corrected mortality, $c=$ mortality (\%) in controls, and $t=$ mortality (\%) in treatments.

\section{Results and discussion}

\section{Collection of baculovirus}

Severe infestation of brown-tail moth, E. chrysorrhoea, was observed during the regular survey in the Ladakh region. Few diseased larvae of E. chrysorrhoea were found to harbour the virus. The body fluid of the dead diseased larvae was found on apricot plant parts (Fig. 2). Observation of discharged body fluid under a phase-contrast microscope revealed numerous spherical particles resembling baculoviral OBs (Fig. 1). The

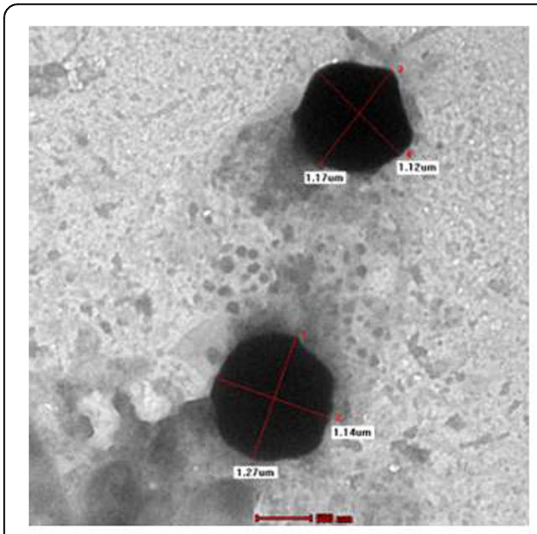

$\mathbf{a}$

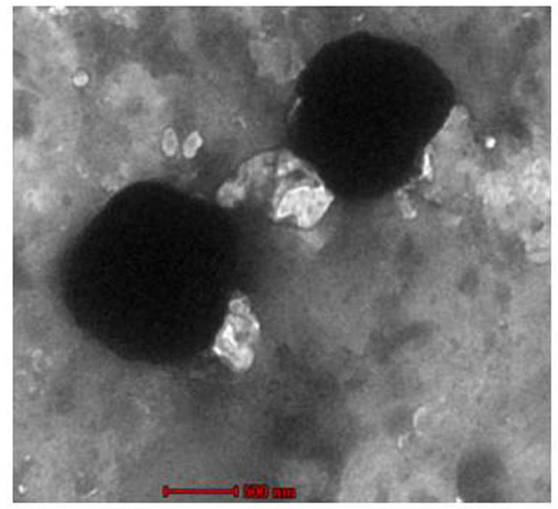

b

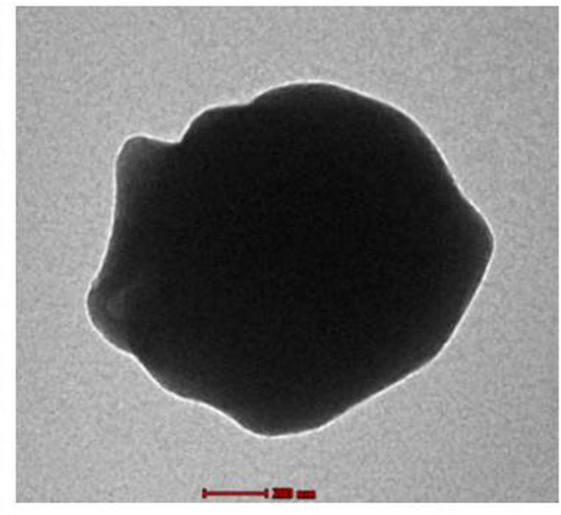

c

Fig. 3 a-c Transmission electron micrographs of occlusion bodies extracted from baculovirus-infected larvae of Euproctis sp. 
periodic outbreak of the brown-tail moth E. chrysorrhoea was reported throughout continental Europe and Britain (Sterling and Speight, 1989) and in India (Tundup et al., 2016 and Lamo, 2017).

\section{Electron microscopic (EM) studies}

Electron microscopic studies revealed the typical baculovirus OBs of type nucleopolyhedrovirus (NPV) with polyhedral structures. Under SEM, the OBs of Euproctis NPV appeared as crystalline structures of variable shapes and sizes ranging from 1.016 to $1.596 \mu \mathrm{m}$ (Fig. 2). Most of the OBs were tetrahedral in shape and few were hexagonal. TEM studies of the OBs also revealed the tetrahedral shape (Fig. 3). The present study clearly revealed the hexagonal and tetrahedral shaped occlusion bodies. The occurrence of NPV on Eucalyptus similis larvae with hexagonal forms of inclusion bodies was reported on mulberry plants (Chu et al., 1975). On the other hand, Ishikawa et al. (1966) found a mixture of nuclear inclusion bodies of tetragonal, triangular, and pentagonal forms in one of the diseased larvae in Japan. Two isolates of NPV of $E$. similis exhibited multi-shaped and cuboidal inclusion bodies, respectively (Watanabe and Aratake, 1974). Senthil Kumar et al. (2015) also recorded that the OBs are tetrahedral in shape in Spilarctia oblique.

\section{Bioassay}

Larval mortality was observed at low doses of Euproctis $\mathrm{NPV}$ with the $\mathrm{LC}_{50}$ of $1 \times 10^{4} \mathrm{OBs} / \mathrm{ml}$ against second instar larvae of E. chrysorrhoea (Table 1). The 95\% fiducial limits ranged from 1.416 to 2.887 . The NPV of the brown-tail moth causes huge declines in its population as well as existing enzootic levels in Europe (Dzuteski, 1960; Kelly et al., 1989 and Speight et al., 1992). NPV was isolated from E. chrysorrhoea population in the UK in 1978; since then, several spray trials have demonstrated that E. chrysorrhoea NPV has considerable potential as a control agent for this insect pest (Kelly et al., 1988 and Speight et al., 1992), and several virus production methods have been developed (Kelly et al., 1989).

Table 1 Mortality percentages of the brown-tail moth, Euproctis chrysorrhoea, larvae in response to nucleopolyhedrovirus ( $N=$

\begin{tabular}{lll}
$50)$ & & \\
\hline $\begin{array}{l}\text { NPV concentration } \\
(\mathrm{OBs} / \mathrm{ml})\end{array}$ & Number of insects killed & ${ }^{\#}$ Mortality (\%) \\
\hline $1 \times 10^{8}$ & $45 \pm 3.7$ & $88.89 \pm 9.9 \mathrm{a}$ \\
$1 \times 10^{6}$ & $39 \pm 3.1$ & $75.56 \pm 5.2 \mathrm{~b}$ \\
$1 \times 10^{4}$ & $28 \pm 3.1$ & $49.89 \pm 3.9 \mathrm{~d}$ \\
$1 \times 10^{2}$ & $19 \pm 1.6$ & $35.94 \pm 2.7 \mathrm{~d}$ \\
Control & $06 \pm 0.9$ & $12.00 \pm 1.1 \mathrm{e}$ \\
\hline
\end{tabular}

Data are means \pm SE. Values within the same column followed by a different letter are significantly different at $P<0.05$ (Tukey's test). \#Percentage of mortality was corrected by Abbot's formula
Occurrence of E. chrysorrhoea nucleopolyhedrovirus, EcNPV, has been reported in England, central Europe, Russia, and in the USA (Slavicek et al., 2004). This is the first report on the isolation of NPV from brown-tail moth E. chrysorrhoea, which may play an important role in its management.

\section{Conclusion}

The brown-tail moth larvae, E. chrysorrhoea, infected with NPV showed typical baculovirus OBs that have crystalline structures of variable shapes and sizes ranging from 1.016 to $1.596 \mu \mathrm{m}$. Most of the OBs were tetrahedral and a few were hexagonal in shape. The leaf disc bioassay showed the $\mathrm{LC}_{50}$ of $1 \times 10^{4} \mathrm{OBs} / \mathrm{ml}$ against the second instar E. chrysorrhoea larvae. NPV is safe and friendly to the environment, and it could be an ideal component for the integrated pest management approach to controlling the brown-tail moth, which is a major insect pest of apricot.

\section{Acknowledgements}

The authors are thankful to the Leh Hill Developmental Council (LHDC), Ladakh and the department of horticulture, Leh, Ladakh for allowing taking up the survey. We also thank anonymous reviewers for their comments that increased the reliability of the manuscript.

\section{Funding}

Not applicable

Availability of data and materials

All data generated or analysed during this study are included in this manuscript.

\section{Authors' contributions}

$\mathrm{BH}, \mathrm{GS}, \mathrm{MK}, \mathrm{ARW}$, and $\mathrm{CRB}$ designed the experiments and carried out the study. BH, GS, MK, and ARW wrote the manuscript. BH, GS, MK, ARW, and BH analysed the data. $\mathrm{BH}$ and $\mathrm{ARW}$ revised the manuscript. All authors read and approved the final manuscript.

Ethics approval and consent to participate

Not applicable

Consent for publication

Not applicable.

Competing interests

The authors declare that they have no competing interests.

\section{Publisher's Note}

Springer Nature remains neutral with regard to jurisdictional claims in published maps and institutional affiliations.

\section{Author details}

${ }^{1}$ Division of Entomology, Sher-e-Kashmir University of Agricultural Sciences and Technology of Kashmir, Shalimar Campus, Srinagar 190019, India. ${ }^{2}$ High Mountain Entomology Laboratory, Satkana Leh, SKUAST-Kashmir, Ladakh, India. ${ }^{3}$ ICAR-National Bureau of Agricultural Insect Resources (NBAIR), Hebbal, Bengaluru 560024, India. ${ }^{4}$ Department of Nano Science and Technology, Directorate of Natural Resource Management, Tamil Nadu Agricultural University, Coimbatore, Tamil Nadu 641003, India. ${ }^{5}$ World Vegetable Center, South Asia, ICRISAT Campus, Hyderabad 502324, India. 
Received: 20 December 2018 Accepted: 20 February 2019

Published online: 05 March 2019

\section{References}

Abbott WS (1925) A method of computing the effectiveness of an insecticide. J Econ Entomol 18:265-267

Anonymous (2014) Survey report on the incidence and outbreak of defoliator in Ladakh region on apricot. Division of Entomology, Sher-e-Kashmir University of Agricultural Sciences and Technology-Kashmir (SKUAST-K). pp 1-5

Bhagat RC (2018) Biodiversity and systematic checklist of moth caterpillars, belonging to family Crambidae, Erebidae and Tortricidae, affecting host crops and plant species in Jammu \& Kashmir state (India). Int J Curr Res Biosci Plant Biol 5(11):56-67

Chu GK, Xie RD, Zhang HJ, Yao YE, Fang ZJ (1975) On a nuclear polyhedrosis virus of mulberry tussock moth, Euproctis similis Fuessly (Lepidoptera: Lymantridae) and field test for the moth control. Microbiol Sin 15:93-100 (in Chinese)

Dzuteski B (1960) Appearance and control measures against Euproctis chrysorrhoea L. in the post-war period in Macedonia. ZaZaStita Bilja 58:239_ 244

Finney DJ (1971) Probit analysis, 3rd edn. Cambridge University Press, London, p 383

Grzywacz D, Rabindra RJ, Brown M, Jones KA, Parnell M (2011) The Helicoverpa armigera NPV production manual. FAO, www.fao.org. Accessed 19 Sept 2018. pp. 61

Hussain B, Nissar T, Ahmad J, Dar SA, Masoodi TH (2018) Incursion of invasive pests and to explore their pathways for ecotourism concern in Ladakh region for sound quarantine requirement. In $3^{\text {rd }}$ International Research Conference on Ecotourism \& Environment, 29 to 31 July, 2018 organised by Environment \& Social Welfare Society, Khajuraho and SKUAST-K

Ishikawa Y, Tanabe H, Nakayama C, Asayama T (1966) Studies on the nuclear polyhedrosis of Porthesia xanthocampa. J Ser Sci Japan 35:174-180

Kelly PM, Speight MR, Entwistle PF (1989) Mass production and purification of Euproctis chrysorrhoea (L.) nuclear polyhedrosis virus. J Virol Methods 25:9399

Kelly PM, Sterling PH, Speight MR, Entwistle PF (1988) Preliminary spray trials of a nuclear polyhedrosis virus as a control agent for the brown-tail moth, Euproctis chrysorrhoea (L.) (Lepidoptera: Lymantriidae). Bull Entomol Res 78: 227-234

Kumar NS, Murugan K, Zhang W (2008) Additive interaction of Helicoverpa armigera Nucleopolyhedrovirus and Azadirachtin. BioControl 53:869-880

Lamo K (2017) New emerging pest of Apricot in cold desert areas of Ladakh. Agriculture www.biotecharticles.com. Accessed 05 Jan 2019. 1-4

Magholi Z, Abbasipour H, Marzban R (2014) Effects of Helicoverpa armigera nucleopolyhedrosis virus (HaNPV) on the larvae of the diamondback moth, Plutella xylostella (L.) (Lepidoptera: Plutellidae). Plant Protect Sci 50:184-189

Martins T, Montiel R, Medeiros J, Oliveira L, Simões N (2005) Occurrence and characterization of a nucleopolyhedrovirus from Spodoptera littoralis (Lepidoptera: Noctuidae) isolated in the Azores. J Invertebr Pathol 89:185-192

Raghuvanshi MS, Gupta V, Stanzin J, Dorjey N, Chauhan SK (2016) Introduction of new insect pests on apricot and its preliminary management options in cold arid region of Ladakh. Indian J Ecol 43:590-592

Senthil Kumar CM, Jacob TK, Devasahayam S, Silva SD, Jinsha J, Rajna S (2015) Occurrence and characterization of a tetrahedral nucleopolyhedrovirus from Spilarctia obliqua (Walker). J Invert Pathol 132:135-142

Slavicek J, Elkinton J, Podgwaite J (2004) Control of the brown-tail moth in maine with a baculovirus. Proceedings, XV USDA Inter Agency Research Forum on Gypsy Moth and Other Invasive Species. pp. 73

Speight MR, Kelly PM, Sterling PH, Entwistle P (1992) Field application of a nuclear polyhedrosis virus against the brown-tail moth, Euproctis chrysorrhoea (L.) (Lep., Lymantriidae). J App Entomol 113:295-306

Sterling PH (1983) Brown-tail: the invisible itch. Antenna 7:110-113

Sterling PH, Speight MR (1989) Comparative mortalities of the brown-tail moth, Euproctis chrysorrhoea (L.) (Lepidoptera: Lymantriidae), in South-East England. Botan J Lin Soc 101:69-78

Tundup P, Wani MA, Dawa S, Hussain S, Rai AP (2016) Influence of climate change on traditional agriculture of cold desert region-Ladakh. Global J Biosci Biotech 5(4):449-452

Watanabe H, Aratake Y (1974) Two isolates of a nuclear-Polyhedrosis virus of the Brown-tail moth, Euproctis similis, exhibiting different inclusion body shapes. J Invert Pathol 24:383-386
You LS, Xiong SL, Cao KC (1983) New records of Apanteles Forster (hymenoptera: Braconidae) from China. Acta Entomol Sinica 26(4):469

\section{Submit your manuscript to a SpringerOpen ${ }^{\circ}$ journal and benefit from:}

- Convenient online submission

Rigorous peer review

- Open access: articles freely available online

- High visibility within the field

- Retaining the copyright to your article

Submit your next manuscript at $\boldsymbol{\nabla}$ springeropen.com 